\title{
STRESZCZENIE DIARIUSZA WOJENNEGO KAZIMIERZA DŁUŻEWSKIEGO Z LAT 1683-1696*
}

Zbigniew Hundert

http://orcid.org/0000-0002-5088-2465

Zamek Królewski w Warszawie

\section{ABSTRACT \\ SUMMARY OF KAZIMIERZ DŁUŻEWSKI'S WAR DIARY FROM 1683-1696}

Kazimierz Dłużewski (died in 1725), was the deputy cup bearer of Chełm, until 1694 a Hussar officer under King John III's winged Hussar banner, afterwards a lieutenant of a light cavalry banner, and a participant of the Polish-Turkish war of 1683-1699. He wrote a diary which survived only in the form of a summary. Dłużewski described in it military actions from the period of 16831696, i.e. from the relief of Vienna to Baranowski confederation. A current edition of this diary is based on the manuscript from the Zamojski Library (Biblioteka Ordynacji Zamoyskiej).

Key words: Kazimierz Dłużewski, the Polish-Ottoman War 1683-1699, Jan III Sobieski Hussars Banner (the Military Unit).

Słowa kluczowe: Kazimierz Dłużewski, wojna polsko-turecka 1683-1699, chorągiew husarska Jana III.

W zasobie Biblioteki Ordynacji Zamojskiej o sygnaturze 837 - depozycie trwałym rękopisów Biblioteki Narodowej w Warszawie - znajduje się, w formie diariusza wydarzeń wojennych z lat 1683-1696, streszczenie rękopiśmiennej książki/ pamiętnika dworzanina królewskiego i wieloletniego towarzysza jazdy oraz oficera armii koronnej Kazimierza Dłużewskiego. Diariusz ten stanowi przedmiot niniejszej edycji źródłowej ${ }^{1}$.

${ }^{*}$ Za konsultacje i pomoc w dotarciu do niektórych materiałów źródłowych chciałem złożyć serdeczne podziękowania prof. Markowi Wagnerowi, dr. Krzysztofowi Kossarzeckiemu, Janowi Jerzemu Sowie oraz Bartoszowi Staręgowskiemu.

1 Memoranda z ksiązki rękopisma jmp. Dlużewskiego, kawalera $w$ wojsku polskim za Jana III, Biblioteka Narodowa w Warszawie, Biblioteka Ordynacji Zamojskiej, rkps 837, s. 224-238.

Adres do korespondencji: zb.hundert@gmail.com 
Autor diariusza doczekał się naukowego, aczkolwiek lakonicznego biogramu autorstwa Kazimierza Piwarskiego jeszcze w okresie międzywojennym ${ }^{2}$. Na obecnym etapie badań dotychczasowe ustalenia na temat Kazimierza Dłużewskiego możemy znacznie poszerzyć, co niestety w dalszym ciągu nie pozwoli nam na wyczerpujące zapełnienie luk w biografii tego zmarłego w 1725 roku jako kasztelan chełmski weterana wojen z Imperium Osmańskim schyłku XVII stulecia ${ }^{3}$. Pochodził on z rodziny pieczętującej się herbem Pobóg, a wywodzącej się z Dłużewa i Woli Dłużewskiej w ziemi czerskiej województwa mazowieckiego. Był synem Anny ze Stawskich i aktywnego publicznie Krzysztofa - który razem ze swym bratem Franciszkiem podpisał suffragia Michała Korybuta w 1669 roku z województwem lubelskim ${ }^{4}$. Krzysztof z Anną mieli jeszcze trzech synów (chyba starszych od Kazimierza): Jana, Andrzeja i Tomasza. Pierwszy z nich, Jan, zrobił karierę duchowną, najpierw jako kanonik poznański i przemyski, później zaś jako kantor kamieniecki, oficjał i proboszcz łukowski, proboszcz zbuczyński, ratneński i porażeński, wreszcie sufragan chełmski i administrator biskupstwa kamienieckiego w 1700 roku. Z nadania Stanisława I Leszczyńskiego został nawet mianowany biskupem kamienieckim 5 . Z pozostałych braci niewiele wiemy o Andrzeju - w przeciwieństwie do Tomasza i Kazimierza, którzy wybrali ścieżkę kariery wojskowej, podobnie jak stryj Franciszek. Na temat działalności wojskowej tego ostatniego wiemy jedynie - $\mathrm{i}$ to z diariusza K. Dłużewskiego, że brał udział w kampanii wiedeńskiej i poległ w pierwszej bitwie pod Parkanami 7 października 1683 roku $^{6}$. O wiele więcej możemy natomiast powiedzieć o Tomaszu (zm. ok. 1698 r.), który niedawno doczekał się naukowego biogramu? ${ }^{7}$. Do jego osoby brat zresztą nawiązywał w publikowanym poniżej diariuszu.

W okresie wojny Rzeczypospolitej z Imperium Osmańskim w latach 1683-1699 Dłużewski służył najpierw jako towarzysz w chorągwi husarskiej króla Jana III w kompucie koronnym, a od 1694 roku, jak przekazuje sam zainteresowany - jako porucznik jazdy. Z diariusza późniejszego kasztelana chełmskiego wynika, że to-

2 K. Piwarski, Dtużewski Kazimierz [w:] Polski Stownik Biograficzny [dalej: PSB], t. 5, 19391946, s. 199.

3 Kazimierz Dłużewski, zdaniem Kazimierza Piwarskiego (ibidem, s. 199), zmarł w 1726 r. Musiało to jednak nastąpić rok wcześniej, albowiem następca Dłużewskiego na urzędzie kasztelana chełmskiego, Piotr Michał Miączyński, nominację na ten urząd uzyskał po śmierci poprzednika 14 VIII 1725. Zob. Urzędnicy dawnej Rzeczypospolitej XII-XVIII wieku, red. A. Gąsiorowski, t. 3, z. 2: Urzędnicy województwa betskiego i ziemi chetmskiej XIV-XVIII wieku [dalej: Urzędnicy betscy i chetmscy], oprac. H. Gmiterek, R. Szczygieł, Kórnik 1992, s. 154-155.

4 Suffragia województw i ziem koronnych $i$ Wielkiego Księstwa Litewskiego, zgodnie na najjaśniejszego króla Michała obranego [...]. Dane między Warszawą a Wola dnia 19 VI 1669, Archiwum Główne Akt Dawnych w Warszawie [dalej: AGAD], Nabytki Niedokumentowe Oddziału I, sygn. 199, k. 432.

5 O Dłużewskich na podstawie: A. Boniecki, Herbarz Polski, t. 4, Warszawa 1901, s. 295-296.

${ }_{6}$ Memoranda z ksiązki..., s. 225. Formacja, w której służbę pełnił F. Dłużewski, oraz jego ranga, pozostają nieznane.

7 M. Wagner, Dlużewski Tomasz [w:] idem, Stownik biograficzny oficerów polskich drugiej połowy XVII wieku [dalej: SBOP], t. 2, Oświęcim 2014, s. 72-73. Niektóre zawarte tam informacje są dyskusyjne.

8 Memoranda z książki..., s. 235. 
warzyszem chorągwi husarskiej JKM był już na pewno w 1686 roku $^{9}$ - ale prawdopodobnie w szeregach tego oddziału walczył od początku wojny, a więc od kampanii wiedeńskiej. Nie możemy tego zweryfikować, ponieważ rejestry popisowe husarii królewskiej dla lat 1679-1688 się nie zachowały lub nie zostały jeszcze odnalezione. W ostatnim ze znanych rejestrów dla tej jednostki z lat 70. XVII wieku - z I kwartału roku $1679^{10}$, nazwisko Dłużewskiego nie występowało, natomiast w III kwartale 1688 roku autor publikowanego diariusza był zapisany w poczcie trzykonnym na dość wysokim miejscu, co oznacza, że musiał w tej chorągwi odbywać już kilkuletnią służbę (zapewne od $1683 \mathrm{r}$.). Dłużewski po raz ostatni figurował w wykazach roty JKM (po 1690 r. w poczcie dwukonnym) w IV kwartale 1693 roku, kończącym się z dniem ostatniego stycznia roku 1694. W ten sposób analiza rejestrów popisowych chorągwi husarskiej Jana III z lat $1688-1696^{11}$ uzupełnia się z informacją podaną przez samego Dłużewskiego, że w 1694 roku uzyskał godność oficerską.

Dłużewski służbę w husarii królewskiej łączył z powinnościami dworzanina JKM. W tym charakterze, a także jako towarzysz roty husarskiej Jana III został odnotowany w akcie nadania mu pierwszego urzędu ziemskiego - podczaszostwa chełmskiego 4 marca 1689 roku $^{12}$. Od tamtej pory stał się aktywnym działaczem na forum sejmikowym ziemi chełmskiej województwa ruskiego, a jego związki z dworem przydawały się lokalnej społeczności. Potwierdza to przekaz rezydenta na dworze królewskim, Kazimierza Sarneckiego z 8 listopada 1693 roku, w którym możemy przeczytać, że „,...] poseł ziemi chełmskiej jmp. Dłużewski, towarzysz usarski JKM, uskarżał się na przechody et gravamina, od wojska W.Ks.L. poczynione tej ziemi, czytał instrukcyją kryminalną, bo i zabójcami, i złodziejami poczynił rycerstwo litewskie" "13. Jak widać, retoryka posła chełmskiego była ostra, ale niewątpliwie zgodna z oczekiwaniami współbraci. Negatywny stosunek Dłużewskiego do wojsk Wielkiego Księstwa można zaobserwować też na kartach jego diariusza, zwłaszcza w opisie działań zbrojnych kampanii żwanieckiej w 1684 roku.

Dłużewski, wkrótce po nominacji na swój pierwszy urząd ziemski, został marszałkiem sejmiku przedsejmowego ziemi chełmskiej 5 grudnia 1689 roku. Jego

9 Dowodzi tego również list do Dłużewskiego, nadany przez kolegę z roty husarskiej JKM Aleksandra Kurdwanowskiego. Zob. tenże do K. Dłużewskiego, Medyka, 26 III 1686, AGAD, Archiwum Publiczne Potockich [dalej: APP], sygn. 163a, t. 15, s. 375-376.

10 Rejestr popisowy chorągwi husarskiej JKM w I kwartale 1679, AGAD, Akta Skarbowo-Wojskowe [dalej: ASW], dz. 85, sygn. 115, k. 89v-90.

${ }_{11}$ Rejestry popisowe chorągwi husarskiej JKM w okresie służby III kwartał 1688 - IV kwartał 1696, Biblioteka Zakładu Narodowego im. Ossolińskich we Wrocławiu [dalej: BOss.], rkps 11906/III, t. 1, s. 161-240. Rejestry te pochodzą ze zbiorów dowódcy tego oddziału, pułkownika JKM i cześnika koronnego, Mikołaja Jana Złotnickiego.

12 Oblata Pocillatura Chetmien. G. Dlużewski, Warszawa, 4 III 1689 r., AGAD, Metryka Koronna, sygn. 376, k. 6v-7; por. Urzędnicy betscy i chetmscy, s. 169. W tym charakterze Dłużewskiego, z tym że pod rokiem 1690, odnotowują także A. Boniecki (op. cit., s. 296), a za nim K. Piwarski (Dlużewski Kazimierz..., s. 199).

13 K. Sarnecki, Pamiętniki z czasów Jana Sobieskiego. Diariusze i relacje z lat 1691-1696, oprac. J. Woliński, Wrocław 1958, s. 57. Tę samą informację zamieszcza K. Piwarski, ale misję poselską Dłużewskiego datuje nie na rok 1693 a na 1689 (zob. idem, Dlużewski Kazimierz..., s. 199). 
aktywność w tej prowincji wzrosła w latach późniejszych, zwłaszcza po śmierci Jana III. Dwukrotnie pełnił powinność posła ziemi chełmskiej na sejmy - w 1697 roku na elekcyjny, a w 1699 roku na pacyfikacyjny. Dwukrotnie wybierano go także deputatem do Trybunału Koronnego $(1706,1714)$ i raz deputatem do komisji skarbowej w 1710 roku. Jako deputat do Trybunału Koronnego w 1714 roku został wybrany także jego marszałkiem ${ }^{14}$. Kolejne urzędy, które Dłużewski otrzymał, również związane były z ziemią chełmską. Dopiero 31 lat po nadaniu podczaszostwa weteran wojen z Portą schyłku XVII wieku został chorążym chełmskim (nominacja z 12 czerwca 1720 r.), a cztery lata później (nominacja z 7 kwietnia 1724 r.) wszedł w skład senatu w randze kasztelana chełmskiego ${ }^{15}$. Aktywizację Dłużewskiego w ziemi chełmskiej niewątpliwie trzeba łączyć z polityką Jana III, która przyniosła królowi pewne korzyści. Zwrócił uwagę na ten aspekt badacz sejmiku chełmskiego Robert Kozyrski, który uznał Dłużewskiego w tej prowincji za wiernego stronnika władcy ${ }^{16}$.

Działalność wojskowa Dłużewskiego przenikała się z działalnością publiczną, co w znacznym stopniu przyspieszyło jego awans oficerski. W podobnym czasie porucznikiem jazdy został również jego brat Tomasz. Służbę towarzyską odbywał już zapewne w 1683 roku razem z Kazimierzem i stryjem Franciszkiem. Jako żołnierz komputu koronnego został wspomniany w 1693 roku przez Kazimierza Sarneckiego. Rezydent na dworze JKM przekazał 6 grudnia, że „P. Dłużewski, towarzysz pancerny jmp. marszałka nadwornego przyprowadził dzikiego znacznego Tatara, który odwód trzymał tych Tatarów, którzy się wybrali w czambuł pod Kamieniec, ale ich z Okopu Św. Trójcy rozgromiono w przeszłym tygodniu" ${ }^{17}$. Jak widać, Tomasz był wówczas towarzyszem chorągwi pancernej marszałka nadwornego koronnego Józefa Karola Lubomirskiego z pułku jazdy JKM, a także towarzyszem oddelegowanym do służby w jeździe Okopów Św. Trójcy ${ }^{18}$. Sarnecki wspomina o nim jeszcze pod datą 5 lipca 1694 roku, że jako żołnierz Okopów walczył z Tatarami pod Hodowem 11 czerwca 1694 roku, oraz że dostał od króla nagrodę w postaci konia, za przyprowadzonego w 1693 roku jeńca tatarskiego ${ }^{19}$. W relacji Sarneckiego z 1694 roku występował już jako towarzysz husarski marszałka nadwornego Lubomirskiego - co

14 Zob. R. Kozyrski, Sejmik szlachecki ziemi chetmskiej 1648-1717, Lublin 2006, s. 78-79, 278, 279, 281, 285, 290, 293. O powierzeniu Dłużewskiemu laski marszałkowskiej Trybunału Koronnego w Lublinie w 1714 r. zob. też: E. Sieniawska do męża, A.M. Sieniawskiego, Lublin, 12 i 23 X 1714 [w:] Korespondencja Elżbiety z Lubomirskich Sieniawskiej, kasztelanowej krakowskiej, t. 1: Z serca kochająca żona i uniżony stuga. Listy Elżbiety z Lubomirskich Sieniawskiej do męża Adama Mikołaja Sieniawskiego z lat 1688-1726, oprac. B. Popiołek, U. Kicińska, A. Sła by, Warszawa-Bellerive-sur-Allier 2016, s. 374, 381.

15 Urzędnicy betscy i chetmscy, s. 147, 154.

16 R. Kozyrski, op. cit., s. 188, przyp. 177.

17 K. Sarnecki, op. cit., s. 70.

18 Dłużewskiego nie odnajdziemy wprawdzie w rejestrach popisowych chorągwi Okopów Św. Trójcy oddelegowanych spod komputowych rot jazdy w okresie służby od października 1693 do października 1694 - co nie oznacza, że nie mógł zmienić któregoś z żołnierzy pierwotnie przeznaczonego do służby w Okopach w tym czasie. Zob. J.J. S ow a , „Ludzie niezwalczeni”. Rejestry choragwi jazdy autoramentu narodowego w Okopach św. Trójcy, 1693-1695 [w:] Studia nad staropolska sztuka wojenna, t. 2, red. Z. Hundert, Oświęcim 2013, s. 259-282.

19 K. Sarnecki, op. cit., s. 149. 
oznacza, że po 6 grudnia 1693 roku zmienił przydział do chorągwi - albo Sarnecki w którymś miejscu popełnił błąd, to jest Dłużewski był towarzyszem pancernym lub husarskim Lubomirskiego. Tego na obecnym etapie badań nie jesteśmy w stanie rozstrzygnąćc ${ }^{20}$.

Zgodnie z dokumentacją komisji hibernowej z 1695 roku largicje (tj. pensje oficerskie z funduszu hibernowego za miniony rok) otrzymało dwóch poruczników Dłużewskich (bez podania imion) - jeden $\mathrm{z}$ chorągwi pancernej starosty kazimierskiego Jerzego Dominika Lubomirskiego, drugi z chorągwi pancernej pisarza polnego koronnego Stefana Stanisława Czarnieckiego ${ }^{21}$. Zdaniem Marka Wagnera Tomasz był wówczas porucznikiem Lubomirskiego ${ }^{22}$, co w tych okolicznościach oznacza, że Kazimierz dowodził w chorągwi Czarnieckiego. Można się z tym zgodzić, choćby $\mathrm{z}$ tej przyczyny, że chorągiew pisarza polnego od 1679 roku była dotowana w systemie repartycji przez ziemię chełmską ${ }^{23}$. Fakt, że rota Czanieckiego wchodziła w dość bliskie związki z tą ziemią, może potwierdzić przypuszczenia, że jej porucznikiem był Dłużewski, aktywny działacz na forum sejmiku chełmskiego.

W przypadku podczaszego chełmskiego warto odnotować, że po śmierci Jana III, w czasie gdy zawiązano konfederację wojskową pod przywództwem Piotra Bogusława Baranowskiego, był jednym z komisarzy do traktowania ze skonfederowanymi żołnierzami. W związku z tym w 1698 roku sejmik chełmski „,in vim kosztów i fatygi w pracowitej funkcjej komisarskiej” zlecił wypłacić Dłużewskiemu 2000 zł z czopowego ${ }^{24}$. Należy w tym miejscu zaznaczyć, że publikowany diariusz kończy się właśnie wątkiem konfederacji Baranowskiego, której Dłużewski nie był zwolennikiem, w przeciwieństwie do brata Tomasza, aktywnego w działaniach związku ${ }^{25}$. Podczaszy chełmski, co warto dodać, był nawet wykorzystany, zapewne przez kasztelana krakowskiego i hetmana wielkiego koronnego Stanisława Jana Jabłonowskiego, do pozyskania deputatów od skonfederowanej armii za pomocą przekupstwa ${ }^{26}$.

20 Zdaniem M. Wagnera T. Dłużewski jeszcze w 1691 r. był towarzyszem innego Lubomirskiego starosty kazimierskiego Jerzego Dominika. Zob. idem, Dlużewski Tomasz..., s. 72-73.

21 Dokumentacja komisji hibernowej 1695 r., Центральний Державний Історичний Архів України, м. Львів [dalej: CDIAUL], F. 10, op. 1, sygn. 115 i Biblioteka XX. Czartoryskich w Krakowie [dalej: B. Czart.], rkps 2524. Informacje te zawdzięczam uprzejmości Jana Jerzego Sowy.

22 M. Wagner, Dlużewski Tomasz..., s. 72-73.

23 Z. Hundert, Wykaz repartycji jednostek wojska koronnego, zgodnie z podziałem komisji lwowskiej w 1679 roku, „Przegląd Historyczno-Wojskowy” [dalej: PHW] 2016, t. 58, z. 2-3, s. 28. Przydział chorągwi Czarnieckiego do ziemi chełmskiej utrzymano także w repartycji opracowanej w 1690 r. i która obowiązywała w czasie, gdy K. Dłużewski był już porucznikiem. Zob. Podziat wojska JKM i Rzptej z komputu na sejmie teraźniejszym anni 1690 postanowionego w skrypcie ad Archivum danym wyrażonego, ad proportionem no. 45 podymnych na tymże sejmie in vim placy płacy wojsku pomienionemu deklarowanych uczyniony, B. Czart., rkps 2562, s. 37.

24 Laudum sejmiku elekcyjnego ziemi chełmskiej, Chełm, 15 IX 1698, Archiwum Państwowe w Lublinie, Księgi Grodzkie Chełmskie - relacyjne (akta luźne), sygn. 9, k. 33; por. R. Kozyrski, op. cit., s. 108-109.

25 Zob. ks. Tomasz Perkowicz do Anny z Gnińskich Zamoyskiej, Lwów, 13 II 1697, AGAD, Archiwum Zamoyskich [dalej: AZ], sygn. 1380, s. 235; M. Wagner, Dlużewski Tomasz ..., s. 73.

26 Zob. Wydatek na rozwiazanie zwiazku [1697], Львівська Національна Наукова Бібліотека України імені Василя Стефаника [dalej: LNNBU], F. 103 (sapieżyński), dz. I, nr 6475. 
O dalszych losach wojennych Dłużewskiego po 1696 roku, przede wszystkim w trakcie Wielkiej Wojny Północnej, wiemy obecnie niewiele. W 1703 roku podczaszy chełmski z rozkazu ówczesnego kasztelana krakowskiego i hetmana wielkiego koronnego Hieronima Augustyna Lubomirskiego sprawował komendę nad wydzieloną grupą wojska. Na jej czele wykonał podjazd pod Warszawę, gdzie rozbił oddział 200 Szwedów, z których wziął do niewoli 32 jeńców, w tym pięciu oficerów ${ }^{27}$. W 1710 roku, jak identyfikuje go heraldyk Adam Boniecki, był już pułkownikiem $\mathrm{JKM}^{28}$. W 1714 roku - w tej właśnie randze (i jako podczaszy chełmski) - podpisał rejestr popisowy chorągwi husarskiej wojewody podlaskiego i hetmana polnego koronnego Stanisława Mateusza Rzewuskiego ${ }^{29}$. Oznacza to, że był wówczas dowódcą husarii i pułku hetmańskiego, a więc dowódcą zajmującym relatywnie wysoką lokatę w gronie koronnego korpusu oficerów. Kariera wojskowa Dłużewskiego rozpoczęta w czasach Jana III, jak widać, w dobie wojny północnej profitowała. Na obecnym etapie badań nie jestem jednak w stanie stwierdzić, kiedy podczaszy chełmski zakończył swoją służbę w armii koronnej. Co do kwestii jego koligacji rodzinnych oraz spraw majątkowym nadal głównym źródłem wiedzy pozostaje herbarz Bonieckiego ${ }^{30}$.

Kazimierz Dłużewski w okresie, który obejmuje publikowany niżej diariusz, jak już wiemy, odbywał służbę wojskową, najpierw w randze towarzysza husarskiego w chorągwi monarchy, a więc w najbardziej prestiżowym oddziale komputu koronnego, a następnie jako porucznik chorągwi pancernej. Jednocześnie był aktywny w życiu publicznym i miał silne związki z dworem królewskim, popierając go z całą stanowczością. Diariusz wojenny Dłużewskiego został zatem napisany przez naocznego świadka i uczestnika wydarzeń. Nie wiemy, jak wyglądał oryginał całego pamiętnika - i w jaki sposób dokonano późniejszego streszczenia, które jest przedmiotem niniejszej edycji, ale mimo to możemy je uznać ze cenne źródło wiedzy. Zawiera opinie, które mogą być reprezentatywne dla grupy zawodowej i warstwy społecznej, do których Dłużewski się zaliczał. Opisywane przez podczaszego chełmskiego wydarzenia mają w zdecydowanej większości potwierdzenie w innym materiale źródłowym, a popełnione błędy są nieliczne - i na ogół odnoszą się do błędnej datacji - dziennej, miesięcznej, a w jednym tylko przypadku - rocznej (data bitwy pod Hodowem). Tego typu błędy były jednak nie do uniknięcia, zważywszy, że Dłużewski swoje wspomnienia kreślił po latach. Niewątpliwie diariusz podczaszego chełmskiego jest cenny, nie tylko ze względu na sformułowane opinie czy

27 K. Piwarski, Hieronim Lubomirski. Hetman wielki koronny, Oświęcim 2015 (reprint z 1929 r.), s. 99, 108; J. Wimmer, Wojsko Rzeczypospolitej w dobie wojny pótnocnej 1700-1717, Warszawa 1956, s. 239.

28 A. Boniecki, op. cit., s. 296.

29 Rejestr chorągwi husarskiej S.M. Rzewuskiego na potrzeby hiberny, 23 XI 1714, CDIAUL, F. 181, op. 2, nr 2322, s. 16-17 - na podstawie wypisów prof. dr. hab. Mirosława Nagielskiego.

30 A. B oni e cki, op. cit., s. 296. Kazimierz żonaty był z Barbarą Podoską. Z tego małżeństwa miał córkę Agnieszkę, wydaną za Franciszka Węglińskiego, podkomorzego chełmskiego, oraz synów: Idziego Franciszka, Stanisława Mateusza i być może Zygmunta, starostę zgierskiego, ożenionego z Katarzyną Gorzyńską. Informacje dotyczące rodziny można uzupełnić o zapisy diariusza Dłużewskiego: żona Kazimierza zmarła w 1693 r., tak samo jak nieznana z imienia bratowa i małżonka Tomasza. Zob. Memoranda z ksiązki..., s. 234. 
dobór wydarzeń, które autor uznał za stosowne odnotować, ale także ze względu na szereg informacji, które mogą stanowić świetny materiał do badań biograficznych i prozopograficznych.

Diariusz Dłużewskiego może stanowić dobre uzupełnienie niedawno opublikowanej przez Marka Wagnera edycji materiałów źródłowych do dziejów wojny polsko-tureckiej 1683-169931. Konflikt ten, podobnie zresztą jak cały „powiedeński” okres panowania Jana III (1684-1696), są nadal niewystarczająco dobrze naświetlone przez polską historiografię. Kalendarium Dłużewskiego może się też uzupełniać z innymi podobnymi diariuszami jemu współczesnych - choćby tym autorstwa Mikołaja Jana Złotnickiego ${ }^{32}$, od 1688 roku dowódcy chorągwi husarskiej Jana III w kompucie koronnym (a więc przełożonego Dłużewskiego), towarzysza husarskiego JKM, z tym że w kompucie litewskim - Aleksandra Dionizego Skorobohatego ${ }^{33}$ czy Franciszka Pułaskiego ${ }^{34}$. Wszystkie one mają charakter kalendarium wydarzeń z poszczególnych lat i przedstawiają okres wojny z Portą 1683-1696/1699. Tego typu diariuszów znamy więcej, jak na przykład pozostający w rękopisie dawnego lwowskiego Ossolineum kalendarium z drugiej połowy XVII wieku autorstwa nieustalonego żołnierza ${ }^{35}$. Ta zależność potwierdza od dawna znany fakt, że pamiętnikarstwo, $\mathrm{w}$ tym to wojskowe, było w epoce staropolskiej szeroko rozpowszechnione, a swoje wspomnienia kreślili nie tylko najwyżsi urzędnicy państwowi i ludzie wysoko urodzeni. Oprócz takich kalendariów przedstawiciele towarzystwa chorągiewnego sporządzali diariusze poszczególnych kampanii wojennych, z których w tym miejscu warto odnotować niedawne edycje diariuszów kampanii wiedeńskiej pióra Michała Polanowskiego i Jerzego Kunaszowskiego ${ }^{36}$. Wszystkie te materiały w zestawieniu

31 Źródta do dziejów wojny polsko-tureckiej w latach 1683-1699, oprac. M. Wagner, Oświęcim 2016.

32 Mikołaj Zlotnicki i jego diariusz wojenny, oprac. M. Wag ner, „Biuletyn Biblioteki Jagiellońskiej” 1994, t. 45, nr 1/2, s. 101-133.

33 A.D. Skorobohaty, Diariusz, oprac. T. Wasilewski, Warszawa 2000.

34 F. Pułaski, Krótka annotacja sejmów warszawskich, grodzieńskich, także elekcyi i koronacyi najjaśniejszych królów ichmościów polskich Jana Kazimierza, Michała, Jana III i Augusta II; tudzież za panowania ich kampanii corocznie odprawionych; publiczniejszych dziejów i rewolucyi ab anno 1648, ad annum 1733, Lublin 1740. Nie ulega kwestii, że przydałoby się nowe, krytyczne wydanie tego starego druku, autorstwa skądinąd zasłużonego żołnierza. Podobnie jak Dłużewski w wojsku służył od ok. 1683 r., by najpóźniej w 1711 r. osiągnąć godność pułkownika jazdy w zaciągu narodowym (również analogicznie do podczaszego chełmskiego). Więcej o nim zob. J.J. Sowa, Formularz z kancelarii hetmańskiej z przełomu XVII i XVIII wieku. Processus sąów hetmańskich... Szymona Franciszka Pułaskiego, „Czasopismo Prawno-Historyczne” 2011, t. 63, z. 2, s. 307-309.

35 Wojna w Polszcze poczynająca się od Kozaków w roku 1648 [do 1701], LNNBU, F. 5 (Ossolińscy), op. 1 , rkps 699 , k. $13 \mathrm{v}-16$.

36 Wojciecha Jerzego Kunaszowskiego diariusz wyprawy wiedeńskiej 1683 roku, oprac. M. Wagner [w:] Studia Historyczno-Wojskowe, t. 5, red. M. Nagielski, K. Bobiatyński, P. Gawron, ZabrzeTarnowskie Góry 2015, s. 288-304; M. Polanowski, Diariusz zemknionego wojska z partii, jako to spod Trembowli, Bucniowej, Śniatynia i Krzemieńca, które kupiło się pod Będzyniem, a stamtad poszło z królem Janem III pod Wiedeń, w tym pod Strygonia, a nazad przez Wegry w roku 1683 [w:] Źródła do dziejów..., s. 12-19. 
z kalendarium Dłużewskiego mogą dać pełniejszy obraz „powiedeńskiego” okresu panowania Jana III oraz całej wojny polsko-tureckiej z lat 1683-1699.

$* * *$

Niniejsza edycja źródłowa została przygotowana według powszechnie stosowanych norm. Pisownia i interpunkcja zostały uwspółcześnione, a uwagi w nawiasach kwadratowych i komentarze w formie przypisów są autorstwa edytora. Te ostatnie zawierają odniesienia do innych materiałów źródłowych oraz opracowań, aby ułatwić odbiór i interpretację wydarzeń zanotowanych przez Kazimierza Dłużewskiego.

[s. 224]

\section{Dokument źródłowy}

Memoranda z książki rękopisma jmp. Dłużewskiego, kawalera w wojsku polskim za Jana III

Kopia: BN, BOZ, rkps 387, s. 224-238.

Roku 1683, dnia 12 września, potrzeba wiedeńska a Dominus Exercituum szczęśliwie wygrana pod waleczną nad narodami komendą najjaśniejszego Jana III. Podskarbi n. Modrzewskii ${ }^{37}$, starosta halicki [s. 225] Potocki ${ }^{38}$ ginie, Kaczkowski, Tatomir porucznicy ${ }^{39}$, towarzystwa circiter sto.

7a 8bris. we czwartek konfuzja pod Parkany ${ }^{40}$. Miserabilis aspectus króla, wodzów wojska. Stabant legiones conscientia flagitii mastae fixis in terram oculis. Wojewoda pomorski Denhoff ścięty ${ }^{41}$; Kaliński, Siemianowski porucznicy ${ }^{42}$. Franciszek Dłużewski, stryj nasz rodzony ginie w tejże potrzebie.

37 Andrzej Modrzewski (vel Modrzejowski), podskarbi nadworny koronny, pułkownik wojska koronnego i rotmistrz chorągwi pancernej w pułku kasztelana krakowskiego Andrzeja Potockiego, jeden z bardziej zaufanych oficerów króla Jana III. Okoliczności śmierci Modrzewskiego, na podstawie edycji źródłowych, szeroko analizuje: R. Sik ora, Husaria pod Wiedniem 1683, Warszawa 2012, s. 218-221.

38 Stanisław Potocki (1659-1683), starosta halicki i kołomyjski, najstarszy syn kasztelana krakowskiego Andrzeja, pułkownik JKM w pułku swego ojca. Więcej zob. M. Wagner, Potocki Stanistaw [w:] PSB, t. 28, 1984-1985, s. 153-154.

39 Andrzej Kaczkowski i Stefan Tatomir. Pierwszy był porucznikiem chorągwi pancernej kasztelana krakowskiego Andrzeja Potockiego, drugi - porucznikiem chorągwi pancernej starosty rzeczyckiego Andrzeja Rzeczyckiego. Zob. M. Polanowski, op. cit., s. 14; rejestry popisowe chorągwi kozackiej A. Potockiego z lat 1677-1679 z podpisami Kaczkowskiego, AGAD, ASW, dz. 85, sygn. 115, k. 91-97. Porucznika Tatomira pod imieniem Stefan wzmiankuje protestacja jego brata Piotra, wniesiona do ksiąg grodzkich halickich 14 XII 1684. Zob. CDIAUL, F. 5, op. 1, sygn. 186, s. 1055-1059.

40 Węg. Párkány, niem. Gockern, obecnie Štúrovo - miasto na Słowacji, przy granicy z Węgrami.

${ }^{41}$ Władysław Denhoff (1639-1683), wojewoda pomorski, starosta kościerski. Więcej zob. J. Pietrzak, Władystaw Denhoff i jego „bohaterska” śmierć w czasie pierwszej bitwy pod Parkánami (7 X 1683) $w$ świetle oracji pogrzebowych, „Kwartalnik Historii Kultury Materialnej” 2016, t. 64, z. 2, s. 169-185.

42 Konstanty Kaliński, porucznik chorągwi husarskiej biskupa płockiego Stanisława Dąmbskiego oraz Andrzej Siemianowski, skarbnik wieluński (od 1671 r.) i porucznik chorągwi husarskiej kasztelana rozpierskiego Wojciecha Urbańskiego. Więcej na ich temat zob. Z. Hundert, Organizacja husarii 
9a 8bris. Bóg Miłościwy erexit cornu populi sui; dwóch paszów żywcem wzięto ${ }^{43}$, pięciu zabito ${ }^{44}$. Wezyr budzyński, Kara Mehmed pasza ${ }^{45}$, postrzelony uszedł. Most na Dunaju rozerwał się, maturavit victoriam, siła żywcem pobrano, więcej Neptun ab sumpsit.

An.[ni] 1684 [s. 226]. Żwaniecka z królem jmścią. Litwa ludna i konna w nagrodę omieszkania wiedeńskiej i parkańskiej i opuszczonych kwater na pograniczu węgierskim. Kamieniec mijamy we czwartek ${ }^{46}$. Piątek pod Ormiany ${ }^{47}$ nad Smotryczą bardzo niebezpieczny. Wszystka colluvies Tatarów z chanem $^{48}$, z sołtanami ${ }^{49}$ i ludzie kamienieccy z działami, i z janczarami, dali nam batalią ${ }^{50}$. Noc diremit anceps praelium. W sobotę pod dęmbiną w same południe napadli Tatarowie. Wyżyckiego, Wołodyjowskiego dzidami pokłuto, umarli ${ }^{51}$.

An.[ni] 1685. 29 7bris. Przeszliśmy Bukowinę z jmp. wdą ruskim ${ }^{52}$. W niedzielę Tatarowie [s. 227] niby cum procella w poniedziałek przyszli. Chan i sołtani, i seraskier ${ }^{53}$, w kilku tysięcy. Tydzień cały wojsko w szyku i sprawie

koronnej na kampanię wiedeńska 1683 roku [w:] ,, W hetmańskim trudzie”. Księga Pamiatkowa ku czci Profesora Jana Wimmera, red. Z. Hundert, M. Wagner, Oświęcim 2017, s. 180-183, 186-189.

43 Byli to bejlerbej Sylistrii Mustafa pasza i bejlerbej Siwaszu, Chalil pasza. Zob. M. Polanow ski, op. cit., s. 17; J. Wimmer, Wiedeń 1683. Dzieje kampanii i bitwy, Warszawa 1983, s. 376.

44 Por. Wojciecha Jerzego Kunaszowskiego..., s. 299.

45 Bejlerbej Budy, Kara Mehmed pasza (zm. 1684).

46 Mowa tu o wymarszu wojsk królewskich spod Paniowiec z 4/5 X 1684 na spotkanie z głównymi siłami tatarskimi, które przekroczyły Dniestr pod Chocimiem. Zob. M. Wagner, Kampania żwaniecka 1684 roku, Warszawa 2013, s. 173.

47 Być może Ostrowczany (ukr. Острівчани), obecnie wieś na Ukrainie, w rejonie kamienieckim obwodu chmielnickiego. W historiografii polskiej przyjęto, że to starcie w piątek 6 X 1684 miało miejsce pod wsią Cybulówka w zakolu Smotrycza, 4 km na południe od Kamieńca Podolskiego. M. Wagner, Kampania żwaniecka ..., s. 175.

48 Selim I Gerej, (1631-1704) - chan krymski w latach 1671-1677/1678, 1684-1691, 1692-1699 i $1702-1704$.

49 Synowie Selima I: Dewlet Gerej (1648-1718), kałga sołtan w latach 1683-1691 i Azamat Gerej, nuradyn sołtan w latach 1683-1691.

${ }_{50}$ O bitwie zob. M. Wagner, Kampania żwaniecka..., s. 175-178.

51 Wyżycki, być może Stanisław, jeden z synów Stanisława, chorążego kijowskiego i pułkownika JKM (zm. 1680). Zgodnie z jedną relacją - w 1684 r. był towarzyszem chorągwi pancernej wojewody ruskiego i hetmana wielkiego koronnego Stanisława Jana Jabłonowskiego. W tej samej relacji wspomina się jeszcze, że w potyczkach z Tatarami zginął nie Wołodyjowski, a Jurski, towarzysz roty husarskiej chorążego koronnego Rafała Leszczyńskiego. Zob. „List ze Lwowa...”, Lwów 19 X 1684 [w:] M. Wagner, Kampania żwaniecka..., s. 237. Osoba Wołodyjowskiego pozostaje niezidentyfikowana.

52 Stanisław Jan Jabłonowski (1634-1702), wojewoda ruski w latach 1664-1691, potem kasztelan krakowski, w latach 1683-1702 hetman wielki koronny.

53 Sary Sulejman pasza, seraskier od 1684 r. (zob. D. Kołodziejczyk, Podole pod panowaniem tureckim. Ejalet kamieniecki 1672-1699, Warszawa 1994, s. 108, 110). Imiennie, pod rokiem 1685, wspomina go hetman Jabłonowski w swojej relacji z działań wojennych, przedstawionej na sejmie warszawskim 1688/1689. Zob. Relacyja praeclare gestorum wojska JKM i Rzptej w czteroletnich kampaniach poczawszy anno 1685, aż do teraźniejszego sejmu in anno 1688 zaczętego sup auspicjej wielkiej buławy jw. jmp. Stanisława Jana na Jabłonowie Jabłonowskiego, wdy i generała ziem ruskich, HWK. Expedycyja in facie calej Rzptej na sejmie tymże w senacie 12 february an. supra scripto, Biblioteka Naukowa Polskiej Akademii Umiejętności i Polskiej Akademii Nauk w Krakowie, rkps 1081, s. 20. 
z niemi ${ }^{54}$. Ze środy na czwartek nazad przechodzimy Bukowinę tym miejscem od wieków intentatam. Wozy w nocy palimy, o jedenastej w noc ruszamy się. Venerat quae miscuit omnes hora duce.

An.[ni] 1686. Budziacka z królem jmścią. Na Bojanie ${ }^{55} \mathrm{w}$ Wołoszech szaniec, na Pererycie $^{56}$ drugi, ad perpetuam rei memoriam Jassy homagium oddają, zamek osadzony: Koszkiel oberszterlejtnant strażnika koronnego komendantem ${ }^{57}$. Brozdowskiego [s. 228 ] zniesiono ${ }^{58}$. Potrzeba w sobotę z śp. p. podskarbim n., pułkownikiem moim $^{59}$ pod Złotą Górą na Łopusznej Dolinie ${ }^{60}$, nader szczęśliwa necessitas in loco, spes in virtute, salus ex victoria. Dwadzieścia kilka tysięcy Tatarów, naszych circiter trzy tysiące spe devoraverunt tandem z klęską swoją mężnie odparci za Bożą pomo$\mathrm{caq}^{61}$. W tej potrzebie postrzelony z łuku syn jego sta chełmski ${ }^{62}$, dragonią litewską komenderujący. Godebski, porucznik pułkownikowski ginie ${ }^{63}$. Stąd z całym wojskiem na drugą stronę Prutu, tandem do Jass, stamtąd [s. 229] ku Seretowi, na trzecim noclegu Łużecki, wda podolski ${ }^{64}$ ginie. We czwartek pod Suczawą śp. p. podskarbi,

${ }_{54}$ Mowa tu o starciu pod Bojanem w Mołdawii w poniedziałek 1 X 1685 i o następnym manewrze odwrotu ku granicom Rzeczypospolitej, podjętym po ponad tygodniu, z wtorku na środę 9/10 X 1686. Więcej zob. W. Wasilewski, Wyprawa bukowińska Stanisława Jabłonowskiego w 1685 roku, Warszawa 2002, s. 121-222.

55 Obecnie Bojany (ukr. Бояни) - wieś na Ukrainie, w obwodzie czerniowieckim, w rejonie nowosielickim.

56 Pereryta (rum. Pererîta), obecnie wieś na lewym brzegu Prutu w Mołdawii, na granicy z Rumunią.

57 Jan Fryderyk Koszkiel, oberszterlejtnant regimentu dragońskiego kasztelana sandomierskiego i strażnika koronnego Stefana Bidzińskiego. Zob. M. Wagner, Koszkiel (Koskull, Koschkull von) Jan Fryderyk [w:] SBOP, t. 2, s. 139-140; zob. też rozkaz S.J. Jabłonowskiego osadzenia przez Koszkiela garnizonu w Jassach, obóz pod Cecorą, 18 VIII 1686, BOss., rkps 250/II, k. 88-88v.

58 Paweł Drozdowski, rotmistrz chorągwi wołoskiej. Informacja „o zniesieniu” tyczy się wydarzeń z 13 IX 1686, gdy Tatarzy zagarnęli prowadzony przez Drozdowskiego z Jass prowiant dla wojska. Zob. Cz. Chow aniec, Wyprawa Sobieskiego do Mołdawii w 1686 r., PHW 1931, t. 4, z. 1, s. 89.

59 Michał Florian Rzewuski (zm. 1687), podskarbi nadworny koronny, pułkownik JKM, dowódca chorągwi husarskiej i całego pułku jazdy JKM w latach 1684/1685-1687. Więcej o jego aktywności w kampanii 1686 r. zob. Z. Hun dert, Komputowe oddzialy rodziny królewskiej w kampanii mołdawskiej 1686 roku w świetle rozkazów i sprawozdania sejmowego hetmana wielkiego koronnego Stanistawa Jana Jabłonowskiego [w:] Jarzmo Ligi Świętej? - Jan III Sobieski i Rzeczpospolita w latach 1684-1696, red. D. Milewski, Warszawa 2017, s. 161-186.

60 Obszar dzisiejszej gminy Lăpuşna w okręgu Hînceşti w Mołdawii, która składa się z trzech wiosek: Anini, Lăpuşna i Rusca.

61 Starcie to miało miejsce 24 VIII 1686. Więcej zob. Cz. Chowaniec, op. cit., s. 70-73; Z. Hundert, Komputowe oddziały..., s. 180.

62 Stanisław Mateusz Rzewuski (1662-1728), starosta chełmski po śmierci ojca w 1687 r., przyszły hetman polny (1706) i wielki koronny (1726). W 1686 r. oberszterlejtnant JKM. Relacyja praeclare gestorum wojska JKM..., s. 35.

${ }^{63}$ Godebski, porucznik chorągwi pancernej podskarbiego nadwornego koronnego M.F. Rzewuskiego w pułku jazdy JKM. Wspomniany przez hetmana Jabłonowskiego w tej randze także w kampanii roku 1685 oraz przy okazji śmierci w bitwie z 24 VIII 1686. Zob. Relacyja praeclare gestorum wojska JKM..., s. 6,35 .

${ }^{64}$ Stanisław Karol Łużecki, wojewoda podolski, pułkownik JKM, jeden z najbardziej doświadczonych oficerów koronnych. Poległ nieopodal Jass 18 IX 1686. O okolicznościach śmierci zob. Relacyja praeclare gestorum wojska JKM..., s. 44-45. 
pułkownik mój, tym którym począł szczęściem, consumavit wojnę. Trupa i więźniów siła $^{65}$. W tej okazji towarzysz nasz, p. Bremer, ginie ${ }^{66}$.

An.[ni] 1687. Z królewiczem jmścią ${ }^{67}$ volentibus similes atakowaliśmy Kamieniec. Litwa od Kieszeni aproszowała się ${ }^{68}$. Pułkownik mój śp., na zaczęcie komisjej jedzie do Lwowa, tam po św. Michale trzeciego dnia umiera ${ }^{69}$. Exitus eius amicis tristis, omnibus luctuosus, extraneis etiam ignotisque, non sine cura fuit.

An./ni] 1688. Z jmp. wdą ruskim [s. 230] poszliśmy pod Kamieniec. Sołtan przychodzi, idziem ku Żwańcowi ${ }^{70}$. Potrzeba w sobotę ${ }^{71}$. Tatarowie do nas szykiem przyszli, chorągiew marszałka n. wzięto, z nią Lasockiego ${ }^{72}$. Hetmani od mogił sromotnie przepędzeni. Od Żwańca ku Wasilowu ${ }^{73}$ powróciwszy, Łubieński ${ }^{74}$, sędzia wojskowy ginie, z nim kilkadziesiąt kompanii. Towarzysz nasz p. Świechowski ${ }^{75}$ tamże ginie. P. kasztelan wileński ${ }^{76}$ od Krzywcza ${ }^{77}$ łączy się z nami.

${ }_{65}$ Bitwa $\mathrm{z}$ Tatarami na uroczysku Perehowce niedaleko Suczawy $3 \mathrm{X} 1686$. Więcej zob. Cz. Chowaniec, op. cit., s. 101-102.

${ }^{66}$ Kazimierz Bremer, podstoli drohicki, towarzysz chorągwi husarskiej JKM; zob. Uniwersał królewski, aby nie stosować konstytucji o „usarskiej milicjej” wobec K. Bremera, Żółkiew 21 III 1686. AGAD, Księgi Grodzkie Drohickie - relacyjne, Seria II, sygn. 51, k. 147-147v; zob. też Relacyja praeclare gestorum wojska JKM..., s. 54; Z. Hundert, Komputowe oddziały..., s. 180.

67 Jakub Ludwik Sobieski (1667-1737), pierworodny syn Jana III, nominalny dowódca w kampanii kamienieckiej w 1687 r.

${ }_{68}$ W staropolszczyźnie (z tureckiego) „kieszeń” oznaczała woreczek, sakiewkę lub torebkę. W związku z tym Kieszeń mogła być miejscem położonym w okolicach Kamieńca o walorach naturalnych do ulokowania wojska. Istnienia takiej osady nie stwierdzono. Terminu „Kieszeń” lub „Kieszonka” używali także inni świadkowie epoki. Zob. np. z obozu pod Kamieńcem, 5 X 1684, AGAD, APP, sygn. 162, t. 1, s. 113.

${ }_{69}$ Zdaniem Dłużewskiego Rzewuski zmarł 2 X 1687; z badań biografa podskarbiego nadwornego wynika z kolei, że zmarł 14 X 1686. Zob. M. Nagielski, Rzewuski Michał Florian [w:] PSB, t. 34, 1992, s. 130-133.

${ }^{70}$ Żwaniec (ukr. Жванець), obecnie wieś na Ukrainie, nad Dniestrem, u ujścia Żwańczyka, w obwodzie chmielnickim, w rejonie kamienieckim.

71 Bitwa pod Żwańcem - Paniowcami 21 VIII 1686. Więcej o niej zob. M. Wagner, Kampania kamieniecka 1688 roku [w:] Jarzmo Ligi Świętej?..., s. 202-204.

72 Lasocki, towarzysz w rocie pancernej marszałka nadwornego koronnego Hieronima Augustyna Lubomirskiego. O tym krwawym epizodzie, w którym Lasocki jako piąty w kolejności stawał na czele oddziału zob. Relacyja praeclare gestorum wojska JKM..., s. 86-87.

73 Wasylów (ukr. Васи́лів), obecnie wieś na Ukrainie, w obwodzie czerniowieckim, w rejonie zastawieńskim.

${ }^{74}$ Wojciech Łubieński, podstoli buski i sędzia wojskowy w latach 1680-1688, rotmistrz chorągwi pancernej w pułku jazdy wojewody poznańskiego Rafała Leszczyńskiego. Poległ 3 IX 1688 w potyczce z Tatarami. Zob. Relacyja praeclare gestorum wojska JKM..., s. 91-94.

75 Świechowski, towarzysz chorągwi husarskiej JKM, zapewne krewny Benedykta Świechowskiego, chorążego w tej jednostce.

76 Józef Bogusław Słuszka, od 1685 r. kasztelan wileński i hetman polny litewski.

77 Krzywcze (ukr. Кривче), obecnie wieś na Podolu, w rejonie borszczowskim obwodu tarnopolskiego. 
An.[ni] 1689. Spod Barysza ${ }^{78}$ podjazdem idziem pod Kamieniec, impreza, ubiec fortecę. Tandem blokujemy Kamieniec. Judyckiego ${ }^{79} \mathrm{w}$ aproszach [s. 231] zabito i przy nim wielu. Dział sześć litewskich wzięto. Szturm naznaczony rozstał się. Acribus intiis incurioso fine.

An.[ni] 1690. Z jmp. wdą ruskim spod Barysza ku Niezwiszczom ${ }^{80}$ za Dniestr, stamtąd za Śniatyń ${ }^{81}$ pod Łużany ${ }^{82}$. P. chorąży bracławski ${ }^{83}$ idzie podjazdem, sadza Suczawę, Suczawicę, Dragomirną ${ }^{84}$. Harstall, oberszterlejtnant ks. kurlandzkiego komendantem na Suczawie ${ }^{85}$. Tego roku szarańcza niezliczona, pierwszy raz pod Baryszem dała się widzieć nad wieczorem bardzo wysoko, po tym w kilka dni nad Dniestrem naprzeciw Rakowca ${ }^{86}$ et consequenter ${ }^{87}$.

An.[ni] 1691. Król jmść do Wołoch tymże co na Budziaki gościńcem. Tatarowie przed Pererytą potykają. Iskra - polski Decjusz [s. 232] ginie ${ }^{88}$. Niemiec wzięty przez akord, osadzony ${ }^{89}$. Nieprzyjaciela nie masz. Wojna z elementami, strata

78 Barysz (ukr. Бариш), obecnie wieś na Ukrainie, w obwodzie tarnopolskim, w rejonie buczackim.

79 Judycki, oberszterlejtnant regimentu pieszego wojewody wileńskiego i hetmana wielkiego litewskiego Kazimierza Jana Sapiehy. Więcej zob. S.J. Jabłonowski do Jana III, obóz pod Kamieńcem, 7 IX 1689 w: Źródta do dziejów..., s. 98.

80 Niezwiska (ukr. Незвисько), obecnie wieś na Ukrianie, w rejonie horodeńskim obwodu iwanofrankiwskiego.

81 Śniatyn (ukr. Снятин), obecnie miasto na Ukrainie, w obwodzie iwanofrankiwskim, nad Prutem, siedziba rejonu śniatyńskiego.

82 Łużany (ukr. Лужани), obecnie osiedle typu miejskiego na Ukrainie, w rejonie kocmańskim obwodu czerniowieckiego.

83 Nikodem Żaboklicki (zm. 1706), chorąży bracławski (1676-1693), potem kasztelan i wojewoda podolski, wieloletni porucznik husarski, pułkownik JKM i regimentarz wojsk koronnych. Więcej zob. Z. Hundert, J.J. Sowa, Od towarzysza jazdy do wojewody podolskiego. Przebieg stużby wojskowej Nikodema Żaboklickiego w latach 1656-1706, „Res Historica” 2016, nr 42, s. 127-181.

84 Dragomirna, obecnie miejscowość w Rumunii, położona w północnej części dawnego hospodarstwa mołdawskiego, na Bukowinie, kilkanaście kilometrów na północ od Suczawy.

85 Jerzy von Harstall, obeszterlejtnant regimentu pieszego księcia kurlandzkiego Fryderyka Kazimierza Kettlera. Zdaniem M. Wagnera Harstall był w tym czasie majorem regimentu pieszego Michała Warszyckiego. Zob. M. Wagner, Harstall (Harsztal) von (Jerzy), SBOP, t. 1, s. 118.

86 Rakowiec (ukr. Ракове́ць), obecnie wieś na Ukrainie, w obwodzie iwanofrankiwskim, w rejonie horodeńskim.

87 Na szarańczę w Mołdawii i na Polesiu Kijowskim, która zniszczyła uprawy zboża i trawę na paszę, skarżył się hetman S.J. Jabłonowski. Zob. tenże do Stanisława Antoniego Szczuki, obóz pod Łuką, 4 IX 1690, AGAD, APP, sygn. 163, t. 1, s. 186. Duży ustęp w tej kwestii także: Pamiętniki Krzysztofa Zawiszy, wojewody mińskiego (1666-1721), oprac. J. Bartos zewicz, Warszawa 1862, s. 360.

${ }_{88}$ Wacław Iskra, stolnik buski, pułkownik JKM, porucznik chorągwi husarskiej podkomorzego koronnego Kazimierza Ludwika Bielińskiego. Poległ w starciu z Tatarami pod Pererytą - zdaniem Kazimierza Sarneckiego 12 IX 1691, a zdaniem Przemysława Smolarka 13 IX 1691. Zob. K. Sarnecki, op. cit., s. 4-5, 229-230; P. S molarek, Kampania mołdawska Jana III roku 1691, oprac. Z. Hundert, M. Wagner, Oświęcim 2015, s. 51-52. O W. Iskrze zob. J.J. S ow a, „Dysponuję krwawa pracę moję”. Testamenty oficerów wojska koronnego z ksiąg grodzkich lwowskich z lat 80. XVII wieku [w:] Hortus bellicus. Studia z dziejów wojskowości nowożytnej, red. K. Bobiatyński [et al.], „Biblioteka Epoki Nowożytnej" 2017, z. 5, s. 589-590.

89 Niemiec (Neamț), obecnie Târgu Neamț (t. Tîrgu Neamţ, węg. Németvásár) - miasto w okręgu Neamţ, w Rumunii. O zajęciu i obsadzie Niemca w październiku 1691 r. zob. P. Smolarek, op. cit., s. $62-63$. 
rynsztunków, koni, wozów. Nuża ab iniuriis caeli ledwie przed tym pamiętna, przez jedenaście dni śnieg, deszcz, mróz. Armata i wszystkie amunicyje za Seretem pod Dębiną wkopane: po którą p. kuchmistrz koronny w dzień nowego lata idzie w kilku tysięcy i szczęśliwie sprowadza ${ }^{90}$.

An.[ni] 1692. Wojsko z jmp. krakowskim pod Żwańcem między Dniestrem a Zbruczą. Emulam Carthaginem Kamieńcowi wystawiło imię fortecy Trójca Śs. ${ }^{91}$ Soroka $^{92}$ obroniła się seraskierowi i hospodarowi wołoskiemu ${ }^{93}$. Ciński od Suczawy powracając gloriossime dał odpór [s. 233] Tatarom ${ }^{94}$. Komendantem w okopie Św. Trójcy generał Brandt ${ }^{95}$ : omni exceptione maior.

An.[ni] 1693. Wojsko pod Wasilowem. Szaniec P. Maryi ${ }^{96}$. Kommenderowani z całego wojska wystawili. P. starosta chełmski tegoż roku poseł od króla jmści do hana Selim Gereja, medyjatora między Portą a nami ${ }^{97}$. Tegoż roku res mira relatu: okopowi die 10 junii w dzień piątkowy pod Hodowem ${ }^{98}$ między opłotkami, in viscera Regni zamierzonej imprezie tatarskiej circiter czterdziestu tysięcy nieprzyjaciela po kilkakroć wszystkiem tłumem atakowali potężnie inaudito exemplo, we czterech set ludzi mężny odpór dali ${ }^{99}$. Znać profunde [s. 234] zważywszy: mortem omnibus ex natura aequalem, oblivione apud posteros vel gloria distingui. Ziścili na sobie sławną ową i przykładną Lakonów przeciwko Persom do cnoty pobudkę. W trudnych i ciężkich przygodach im rady mężniejsze tym bezpieczniejsze. Tegoż roku revertentibus post labores w zapustne dni w jeden że tydzień z rodzonym moim obmyśliło nam niebo żony, homestissimum levamentum.

90 Franciszek Zygmunt Gałecki, kuchmistrz koronny, wieloletni dowódca regimentu gwardii dragońskiej JKM. O odwrocie z Mołdawii i o zadaniu sprowadzenia ,zakopanej” artylerii zob. P. Smolarek, op. cit., s. 64-66.

91 Okopy Św. Trójcy, fort usytuowany u ujścia Zbrucza do Dniestru, obecnie (ukr. Окопи) wieś na Ukrainie, w obwodzie tarnopolskim, w rejonie borszczowskim.

92 Soroki (rum. Soroca), obecnie miasto w północno-wschodniej części Mołdawii.

93 Mustafa Büjykly pasza, bejlerbej Sylistrii i seraskier oraz Konsanty Kantemir (1612-1693, rum. Constantin Cantemir), hospodar mołdawski (wołoski) w latach 1685-1693. Więcej o oblężeniu Soroki w 1692 r. zob. Dziennik oblężenia ad 27 września do 9 października posłany Janowi III przez pułkownika [Krzysztofa] Rappe komendanta w Soroce, 1692 r. [w:] Źródła do dziejów wojny..., s. 132-133; M. Markowicz, Rola polskich załóg w twierdzach pólnocnej Mołdawii w systemie obrony pogranicza Rzeczpospolitej w latach 1692-1696 [w:] Jarzmo Ligi Świętej?..., s. 222.

94 Wojciech Cieński, stolnik bracławski, pułkownik JKM.

95 Michał Brandt, na ów czas oberszter JKM, dowódca komputowego regimentu gwardii arkabuzerskiej JKM i komendant garnizonu Okopów Św. Trójcy.

96 Szaniec Panny Marii, fortyfikacje na linii Dniestru, na uroczysku Gródek pod Wasilowem, utworzone w sierpniu 1693 r. Więcej zob. J.J. Sow a, „Ludzie niezwalczeni””..., s. 264.

97 Starosta chełmski Stanisław M. Rzewuski został wysłany do Adrianopola na przełomie lat 1693/1694, gdzie w lutym 1694 prowadził rokowania z chanem Selimem Gerejem. Po bezowocnych pertraktacjach powrócił do Rzeczypospolitej wczesną wiosną, by 19 IV 1694 złożyć sprawozdanie ze swej misji Janowi III. Zob. A. Link-Lenczowski, Rzewuski Stanisław Mateusz, PSB, t. 34, 1992, S. 152 .

98 Hodów (ukr. Годів), obecnie wieś na Ukrainie, w obwodzie tarnopolskim, w rejonie zborowskim.

99 Pomyłka autora, starcie pod Hodowem miało miejsca 11 VI 1694. Więcej na temat tej bitwy pisał: R. Sikora, Niezwykte bitwy i szarże husarii, Warszawa 2011, s. 169-173. 
An.[ni] 1694. Spod Petlikowiec ${ }^{100}$ wojsko pod Kamieniec. Stamtąd ku Żwańcowi, tandem za okop Św. Trójcy; interea Bóg Miłościwy successibus carentes [s. 235] niespodziewaną w dzień Św. Brunona ozdobił victorią, gdy znaczną zaharę do Kamieńca idącą około trzech tysięcy wozów i więcej wozów z przenicami, ryżami, z szafranem, miodem, rodzynkami, figami caeterisque utensilibus dał wziąc non sine sanguine, bo kilkunastu naszych zginęło ${ }^{101}$. Tatarów też kilkunastu znacznych wzięto. Na tę wojnę jużem porucznikowal.

An.[ni] 1695. [W] zimie, w piątek przed ostatkami, czambuł tatarski w ośmiudziesiąt circiter tysięcy pode Lwów prosto podchodzi. Jmp. krakowski z małą garścią ludzi, choć pod tak znaczną u nas fortecą, ledwie defensive mógł stawić aciem ${ }^{102}$. [s. 236] P. Wielhorski, podkomorzy włodzimierski ${ }^{103}$ delicium populi z postrzału umiera. Powietrze w Kamieńcu znaczne. Syn Kahreman $[a]$ paszy kamienieckiego między wielu inszych umiera ${ }^{104}$. Więźniowie nasi prawie wszyscy wymarli: Majkowski, rotmistrz okopowy ${ }^{105}$, Gołecki star., Janowski, Zbrożek, Strzałkowski towarzysz mój, $\mathrm{i}$ innych wiele ${ }^{106}$. Wojsko pomknąwszy się spod Glinian ${ }^{107}$ pod Barysz, spod Barysza pod Petlikowce, stamtąd pod Chmielową ${ }^{108}$ wolało otiari quam nihil agere. Tandem poszliśmy za Wasilów z imprezą dobywania Kamieńca; tam agendi tempora consultando consumpsimus. Litwa się zbuntowała: dziewiętnaście chorągwi wyszło z wojska [s. 237], swoją dywizją poszli nazad ku Buczaczowi ${ }^{109}$. Tandem za powrotem

100 Petlikowce Stare (ukr. Старі Петликівці), obecnie wieś na Ukrainie w rejonie buczackim obwodu tarnopolskiego.

101 Mowa o w rozbiciu pod Uścieszkiem 6 X 1694 tureckiego konwoju zahary dla Kamieńca.

102 Mowa o bitwie pod Lwowem 11 II 1695. Więcej na jej temat zob. W. Majewski, Najazd Tatarów w lutym 1695 r., „Studia i Materiały do Historii Wojskowości” 1963, t. 9, cz. 1, s. 125-178.

103 Jan Kazimierz Wielhorski, podkomorzy włodzimierski, rotmistrz JKM. Zmarł od postrzału w głowę, który otrzymał w bitwie pod Lwowem 11 II 1695. Zob. K. Sarnecki, op. cit., s. 373-375; por. T. Perkowicz do A. Zamoyskiej, Lwów, 16 II 1695, AGAD, AZ, sygn. 1380, s. 95-96.

104 Kahraman Mustafa pasza, bejlerbej kamieniecki od stycznia 1689 r. do 22 IX 1699. Zmarły na zarazę syn Kahramana pozostaje bliżej niezidentyfikowany. Zob. D. Kołodziejczyk, op. cit., s. 126, $153-154,155$.

105 Tomasz Majkowski, towarzysz chorągwi pancernej starosty buskiego Aleksandra Jana Jabłonowskiego, rotmistrz „okopowej” chorągwi pancernej w okresie służby od października 1693 do października 1695. Zob. J.J. Sow a, ,_Ludzie niezwalczeni”..., s. 265, 267, 274, 275, 286, 287.

106 Janowski i Gołecki pozostają niezidentyfikowani; Strzałkowski - towarzysz roty pancernej Stanisława S. Czarnieckiego, pisarza polnego; Zbrożek - być może któryś z towarzystwa „okopowych” chorągwi jazdy i krewny zmarłego ok. 1691 r. strażnika wojskowego Michała Zbrożka. Jeden ze Zbrożków, również imieniem Michał, został w 1693 r. towarzyszem „okopowej” chorągwi pancernej Tomasza Majkowskiego. Inni Zbrożkowie z chorągwi pancernej strażnika wojskowego i stolnika przemyskiego Jana Sobieskiego zostali towarzyszami jazdy „okopowej” w 1694 r.. Zob. J.J. Sowa, „Ludzie niezwalczeni”..., s. 275, 291.

107 Gliniany (ukr. Глиняни), obecnie miasto na Ukrainie, w obwodzie lwowskim, w rejonie złoczowskim.

108 Chmielowa (ukr. Хмелева), obecnie wieś na Ukrainie w obwodzie tarnopolskim, w rejonie zaleszczyckim.

109 Więcej o buncie chorągwi litewskich i ich powrocie pod władzę hetmana polnego J.B. Słuszki w październiku 1695 r. Relacje z dni 18-26 X 1695, zob. K. Sarnecki, op. cit., s. 383-385; zob. też Pamiętniki Krzysztofa Zawiszy..., s. 184. 
naszym rekoncyliowali się z wodzem jmp. wileńskim. Caput seditionis P. Karp, towarzysz p. wdy wileńskiego usarski ${ }^{110}$. Ja z chorągwią byłem pod okopami natenczas.

An.[ni] 1696. Mors eo anno demetendo maiorum gentium capita superbum Tarquinium initata est; summa papaverum decutientiem. Die 18 maj, w dzień Św. Trójcy najjaśniejszy monarcha, król Jan, Ojczyzny Ojciec exemploquo maior umiera ${ }^{111}$. Serce w Warszawie u Kamedułów fundacyi jego ${ }^{112}$. Intestina w Żółkwi u fary. Ciało do Krakowa ${ }^{113}$. Quid mirum toto si spargitur orbe; iacere uno non poterat. Tanta ruina loco. W tymże roku związek ultimis Julii. Marszałkiem Baranowski [s. 238], towarzysz usar. Józefa Lubomirskiego, marszałka koronnego ${ }^{114}$. Quis in arma furentem impulevit populum? Quis pacem excusserit orbi? Przytrudniej będzie wiedziała posteritas; fato Reipublicae stało się w kilku osobach ut pessimum facinus auderent pauci, plures vellent, caeteri paterentur.

\section{BIBLIOGRAFIA}

\section{Źródła rękopiśmienne}

\section{Archiwum Główne Akt Dawnych w Warszawie}

Akta Skarbowo-Wojskowe, dz. 85, sygn. 115.

Archiwum Publiczne Potockich, sygn. 162 (t. 1), 163 (t. 1), 163a (t. 15).

Archiwum Zamoyskich, sygn. 1380.

Księgi Grodzkie Drohickie - relacyjne, Seria II, sygn. 51.

Metryka Koronna, sygn. 376.

Nabytki Niedokumentowe Oddziału I, sygn. 199.

110 Karp, towarzysz roty husarskiej w kompucie litewskim wojewody wileńskiego i hetmana wielkiego litewskiego Kazimierza Jana Sapiehy. Niezidentyfikowany z imienia. Karpiowie byli szeroko rozgałęzioną rodziną w powiecie upickim, ale też na Żmudzi i Podlasiu.

111 Jest to pomyłka autora, albowiem Jan III zmarł w Wilanowie 17 VI 1696.

112 Kościół OO. Kapucynów p. w. Przemienienia Pańskiego Jan III ufundował w Warszawie w 1683 r. jako wotum za zwycięstwa w bitwach pod Chocimiem 1673 i Wiedniem 1683. Budowę ukończono w 1694 r. J. Putkow ska, Architektura Warszawy XVII wieku, Warszawa 1991, s. 220-224.

113 Ciało króla przewieziono do Krakowa dopiero w 1733 r. Do tego czasu trumna ze szczątkami monarchy znajdowała się w kościele OO. Kapucynów w Warszawie przy ulicy Miodowej.

114 Piotr Bogusław Baranowski, towarzysz chorągwi husarskiej marszałka nadwornego koronnego Józefa Karola Lubomirskiego, dyrektor związku wojskowego w latach 1696-1697. Do zawiązania konfederacji doszło w partii wołyńskiej wojska koronnego 23 VIII 1696. Więcej zob. Z. Hundert, J.J. S owa, op. cit., s. 160-164; J.J. Sowa, Zawiazanie konfederacji Baranowskiego a postuszeństwo oficerom i dyscyplina wojskowa [w:] Homo Militans, t. 4: Przysięga wojskowa. Idea i praktyka. Z dziejów wojskowości polskiej i powszechnej, red. A. Niewiński, Oświęcim 2017, s. 80-87. 
Archiwum Państwowe w Lublinie

Księgi Grodzkie Chełmskie - relacyjne (akta luźne), sygn. 9.

Biblioteka Narodowa w Warszawie

Biblioteka Ordynacji Zamojskiej rkps 837.

Biblioteka Naukowa Polskiej Akademii Umiejętności i Polskiej Akademii Nauk w Krakowie

rkps 1081 .

Biblioteka XX. Czartoryskich w Krakowie

rkps $2524,2562$.

Biblioteka Zakładu Narodowego im. Ossolińskich we Wrocławiu rkps 250/II, 11906/III, t. 1.

Centralne Państwowe Historyczne Archiwum Ukrainy we Lwowie (Центральний Державний Історичний Архів України, м. Львів).

F. 5, op. 1, sygn. 186.

F. 10, op. 1, sygn. 115 .

F. 181, op. 2, nr 2322.

Lwowska Narodowa Naukowa Biblioteka Ukrainy imieniem Wasyla Stefanyka (Львівська Національна Наукова Бібліотека України імені Василя Стефраника)

F. 5 (Ossolińscy), op. 1, rkps 699.

F. 103 (sapieżyński), dz. I, nr 6475.

\section{Źródła drukowane}

Korespondencja Elżbiety z Lubomirskich Sieniawskiej, kasztelanowej krakowskiej, t. 1: Z serca kochajaca żona i uniżony sługa. Listy Elżbiety z Lubomirskich Sieniawskiej do męża Adama Mikołaja Sieniawskiego z lat 1688-1726, oprac. B. Popiołek, U. Kicińska, A. Słaby, Warszawa-Bellerive-sur-Allier 2016.

Mikołaj Ztotnicki i jego diariusz wojenny, oprac. M. Wagner, „Biuletyn Biblioteki Jagiellońskiej" 1994, t. 45, nr 1-2. 
Pamiętniki Krzysztofa Zawiszy, wojewody mińskiego (1666-1721), oprac. J. Bartoszewicz, Warszawa 1862.

Pułaski F., Krótka annotacja sejmów warszawskich, grodzieńskich, także elekcyi i koronacyi najjaśniejszych królów ichmościów polskich Jana Kazimierza, Michała, Jana III i Augusta II; tudzież za panowania ich kampanii corocznie odprawionych; publiczniejszych dziejów i rewolucyi ab anno 1648, ad annum 1733, Lublin 1740.

Sarnecki K., Pamiętniki z czasów Jana Sobieskiego. Diariusze i relacje z lat 1691-1696, oprac. J. Woliński, Wrocław 1958.

Skorobohaty A.D., Diariusz, oprac. T. Wasilewski, Warszawa 2000.

Sow J.J., „Dysponuję krwawa pracę moję”. Testamenty oficerów wojska koronnego z ksiag grodzkich lwowskich z lat 80. XVII wieku [w:] Hortus bellicus. Studia z dziejów wojskowości nowożytnej, red. K. Bobiatyński [et al.], „Biblioteka Epoki Nowożytnej” 2017, z. 5.

Sowa J.J., Formularz z kancelarii hetmańskiej z przełomu XVII i XVIII wieku. Processus sqdów hetmańskich... Szymona Franciszka Pułaskiego, „Czasopismo Prawno-Historyczne” 2011, t. 63, z. 2.

Wojciecha Jerzego Kunaszowskiego diariusz wyprawy wiedeńskiej 1683 roku, oprac. M. Wagner [w:] Studia Historyczno-Wojskowe, t. 5, red. M. Nagielski, K. Bobiatyński, P. Gawron, Zabrze-Tarnowskie Góry 2015.

Źródta do dziejów wojny polsko-tureckiej w latach 1683-1699, oprac. M. Wagner, Oświę$\operatorname{cim} 2016$.

\section{Opracowania}

Boniecki A., Herbarz polski, t. 4, Warszawa 1901.

Chowaniec Cz., Wyprawa Sobieskiego do Mołdawii w 1686 r., „Przegląd Historyczno-Wojskowy" 1931, t. 4, z. 1.

Hundert Z., Komputowe oddziały rodziny królewskiej w kampanii mołdawskiej 1686 roku w świetle rozkazów i sprawozdania sejmowego hetmana wielkiego koronnego Stanistawa Jana Jabłonowskiego [w:] Jarzmo Ligi Świętej? - Jan III Sobieski i Rzeczpospolita w latach 1684-1696, red. D. Milewski, Warszawa 2017.

Hundert Z., Organizacja husarii koronnej na kampanię wiedeńska 1683 roku [w:] ,, Whetmańskim trudzie”. Księga Pamiątkowa ku czci Profesora Jana Wimmera, red. Z. Hundert, M. Wagner, Oświęcim 2017.

Hundert Z., Sowa J.J., Od towarzysza jazdy do wojewody podolskiego. Przebieg stużby wojskowej Nikodema Żaboklickiego w latach 1656-1706, „Res Historica” 2016, nr 42.

Hundert Z., Wykaz repartycji jednostek wojska koronnego, zgodnie z podziałem komisji lwowskiej w 1679 roku, „Przegląd Historyczno-Wojskowy” 2016, t. 58, z. 2-3.

Kołodziejczyk D., Podole pod panowaniem tureckim. Ejalet kamieniecki 1672-1699, Warszawa 1994.

Kozyrski R., Sejmik szlachecki ziemi chetmskiej 1648-1717, Lublin 2006.

Link-Lenczowski A., Rzewuski Stanisław Mateusz [w:] Polski Słownik Biograficzny, t. 34, 1992.

Majewski W., Najazd Tatarów w lutym 1695 r., „Studia i Materiały do Historii Wojskowości” 1963, t. 9, cz. 1. 
Markowicz M., Rola polskich załóg w twierdzach pótnocnej Mołdawii w systemie obrony pogranicza Rzeczpospolitej w latach 1692-1696 [w:] Jarzmo Ligi Świętej? - Jan III Sobieski i Rzeczpospolita w latach 1684-1696, red. D. Milewski, Warszawa 2017.

Nagielski M., Rzewuski Michał Florian [w:] Polski Stownik Biograficzny, t. 34, 1992.

Pietrzak J., Władystaw Denhoff i jego ,,bohaterska” śmierć w czasie pierwszej bitwy pod Parkánami (7 X 1683) w świetle oracji pogrzebowych, „Kwartalnik Historii Kultury Materialnej" 2016, t. 64, z. 2.

Piwarski K., Dlużewski Kazimierz [w:] Polski Słownik Biograficzny, t. 5, 1939-1946.

Piwarski K., Hieronim Lubomirski. Hetman wielki koronny, Oświęcim 2015 (reprint z 1929 r.).

Putkowska J., Architektura Warszawy XVII wieku, Warszawa 1991.

Sikora R., Husaria pod Wiedniem 1683, Warszawa 2012.

Sikora R., Niezwykłe bitwy i szarże husarii, Warszawa 2011

Smolarek P., Kampania moldawska Jana III roku 1691, oprac. Z. H u n d e r t, M. Wagner, Oświęcim 2015.

Sowa J.J., „Ludzie niezwalczeni”. Rejestry choragwi jazdy autoramentu narodowego w Okopach św. Trójcy, 1693-1695 [w:] Studia nad staropolską sztuka wojenna, t. 2, red. Z. Hundert, Oświęcim 2013.

Sowa J.J., Zawiązanie konfederacji Baranowskiego a postuszeństwo oficerom i dyscyplina wojskowa [w:] Homo Militans, t. 4: Przysięga wojskowa. Idea i praktyka. Z dziejów wojskowości polskiej i powszechnej, red. A. Niewiński, Oświęcim 2017.

Urzędnicy dawnej Rzeczypospolitej XII-XVIII wieku, red. A. Gąsiorowski, t. 3, z. 2: Urzędnicy województwa betskiego i ziemi chetmskiej XIV-XVIII wieku, oprac. H. Gmiterek, R. Szczygieł, Kórnik 1992.

Wagner M., Kampania kamieniecka 1688 roku [w:] Jarzmo Ligi Świętej? - Jan III Sobieski i Rzeczpospolita w latach 1684-1696, red. D. Milewski, Warszawa 2017.

Wagner M., Kampania żwaniecka 1684 roku, Warszawa 2013.

Wagner M., Potocki Stanistaw [w:] Polski Stownik Biograficzny, t. 28, 1984-1985.

Wagner M., Słownik biograficzny oficerów polskich drugiej połowy XVII wieku, t. 1-2, Oświęcim 2013-2014.

Wasilewski W., Wyprawa bukowińska Stanisława Jabłonowskiego w 1685 roku, Warszawa 2002.

Wimmer J., Wiedeń 1683. Dzieje kampanii i bitwy, Warszawa 1983.

Wimmer J., Wojsko Rzeczypospolitej w dobie wojny pótnocnej 1700-1717, Warszawa 1956. 